\title{
Sebastian Kołodziejczak
}

Uniwersytet Szczeciński

\section{Warunki rozwojowe Szczecina w świadomości jego mieszkańców. Perspektywa zakorzenienia*}

STRESZCZENIE W artykule zaprezentowano wyniki badań przeprowadzonych wśród szczecinian mieszczących się w mobilnych kategoriach wieku produkcyjnego (25-44 lata) nad postrzeganiem stolicy Pomorza Zachodniego przez jej mieszkańców. Ustalenia z analizy wyników badań odnoszą się w poniższym tekście do problematyki: 1) stosunku do władz Szczecina pozwalającego sondować funkcjonujący w świadomości szczecinian obraz lokalnego samorządu w przyjętych do badania aspektach; 2) potencjału rozwojowego i warunków do rozwoju osobistego mieszkańców tworzących podstawę dla jego osiedleńczej atrakcyjności oraz regionalnej konkurencyjności. Istotny kontekst przeprowadzonej analizy tworzy zestawienie sposobów postrzegania miasta ze zmiennymi zakorzenienia (urodzenie w Szczecinie lub osiedlenie się w nim; rodzinne korzenie szczecińske lub ich brak).

\section{SŁOWA KLUCZOWE}

KAPITAK LUDZKI, PERCEPCJA MIASTA, TOŻSAMOŚĆ SPOŁECZNA, SPOŁECZNE ZAKORZENIENIE, WIĘŹ LOKALNA

\footnotetext{
· Artykuł charakteryzujący opinie na temat władz lokalnych i potencjałów rozwojowych Szczecina stanowi kontynuację rozważań podjętych w tekście Alberta Terelaka Szczecin w świadomości jego mieszkańców. Perspektywa zakorzenienia (s. 63-89). Oba teksty są efektem analizy wyników najświeższych (z 2015 r.) badań, prowadzonych wspólnie przez autorów - w dwuletnim interwale - od 2009 r. Wprowadzenie do artykułów stanowią rozważania przedstawione w tekście Alberta Terelaka i Sebastiana Kołodziejczaka Szczecin jako przestrzeń życia i rozwoju w świadomości jego aktywnych zawodowo mieszkańców w kontekście rekompozycji rynków pracy Pomorza Zachodniego (s. 51-62).
} 
Zagadnienia związane z dynamiką procesów rozwojowych Szczecina oraz ich percepcją wśród mieszkańców miasta trudno jest analizować w oderwaniu od roli, jaką odgrywają lokalne władze samorządowe będące jednym z istotnych aktorów, a optymalnie - kreatorów zachodzących procesów społecznych, kulturowych i gospodarczych. Dlatego w przeprowadzonych badaniach jeden z najistotniejszych wymiarów stanowią stwierdzenia opisujące stosunek mieszkańców do władz Szczecina, które z jednej strony odnoszą się do sposobu ich postrzegania, z drugiej zaś zawierają wymiar waloryzacyjny wybranych aspektów ich funkcjonowania. Zastosowane (w kwestionariuszu) stwierdzenia, do których odnosili się szczecinianie uczestniczący w badaniu, odsłaniają zatem ogólny wymiar ich postaw wobec lokalnego samorządu, a jednocześnie stanowią asumpt do dalszych, pogłębionych badań zorientowanych na uzyskanie szczegółowej wiedzy o sposobach postrzegania oraz społecznym oddźwięku dla podejmowanych przez samorząd działań.

Powrót do systemu demokracji lokalnej na początku lat 90. sprawił, że po kilkudziesięciu latach scentralizowanego zarządzania zaczęły odbudowywać się samorządy lokalne, a mieszkańcy uczyli się nie tylko partycypacji społecznej, lecz także sposobów traktowania i oceniania działań przez nie realizowanych. Zgodnie z tym, co pisze Piotr Matczak z zespołem, podsumowując minione ćwierćwiecze, jakkolwiek samo powstanie samorządów lokalnych można uznać za sukces, który zmienił Polskę, jednak sposób, w jaki samorządy działają współcześnie, charakteryzuje się - najogólniej rzecz ujmując - rosnącym dystansem między profesjonalizującymi się i biurokratyzującymi instytucjami władzy a społeczeństwem (por. Matczak, Jeran, Mączka, Nowak, Śliwa, 2015). Dystans natomiast ułatwia ocenę, a szczególnie ocenę krytyczną, co pokazują wyniki przeprowadzonych analiz. W obszarze uogólnionego stosunku szczecinian do władz lokalnych dominuje bowiem niezadowolenie oraz przekonanie o niskiej skuteczności podejmowanych przez nie działań, co przekłada się na słabe warunki do rozwoju osobistego, realizacji życiowych i zawodowych aspiracji mieszkańców. Zdecydowanie wysoko ocenia lokalne władze mniej niż co dwudziesty mieszkaniec. Stosunkowo najlepiej jest w wymiarze ogólnej oceny wyrażanej opiniami wobec stwierdzenia Szczecin ma dobre władze, gdy łącznie pozytywny stosunek (kategorie raczej oraz zdecydowanie) zadeklarowało ponad 26\% mieszkańców. W odniesieniu do stwierdzeń odnoszących się do oceny podejmowanych przez władze działań postawy pozytywne pojawiają się zdecydowanie rzadziej. Większy udział pozytywnych opinii odnoszących się do stwierdzenia Szczecin ma dobre władze należy potraktować jako logiczną konsekwencję opisanego wcześniej emocjonalnego stosunku do miasta zamieszkania, który w niewielkim stopniu znajduje potwierdzenie w sposobie postrzegania konkretnych działań realizowanych przez władze.

Wart podkreślenia jest ponadto fakt, że ogólna opinia o lokalnych władzach związana jest z płcią oraz wykształceniem. Mężczyźni częściej niż kobiety wyrażają negatywne opinie. Z kolei wraz ze wzrostem poziomu wykształcenia maleje udział opinii krytycznych o władzach miasta. Co trzeci szczecinianin legitymujący się dyplomem wyższych studiów $(33,2 \%)$ spogląda na lokalne władze z przychylnością, natomiast wśród osób z wykształceniem średnim zdarza się to w 26,1\% przypadków, zasadniczym zawodowym - 22,7\%, podstawowym i/lub gimnazjalnym - 16,3\%. 
Stosunek do władz Szczecina - zestawienie rozkładów opinii (\%)

Szczecin ma dobre władze

Zdecydowanie nie do zdecydowanie tak

Raczej nie do raczej tak

Trudno powiedzieć

Brak danych

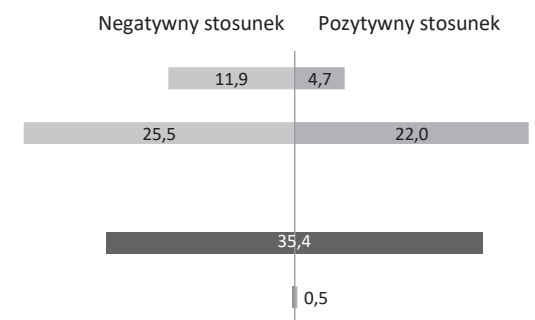

Władza w Szczecinie słabo radzi sobie z tworzeniem warunków sprzyjających rozwojowi miasta

Zdecydowanie tak do zdecydowanie nie

Raczej tak do raczej nie

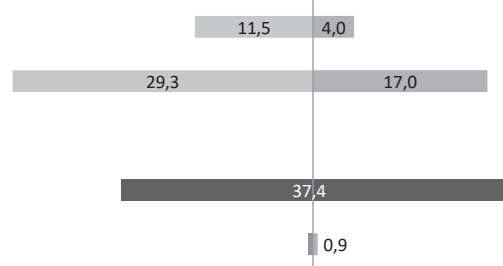

To, co jest dobre w Szczecinie, częściej jest marnotrawione niż wykorzystywane dla jego świetności

Zdecydowanie tak do zdecydowanie nie

Raczej tak do raczej nie

Trudno powiedzieć

Brak danych

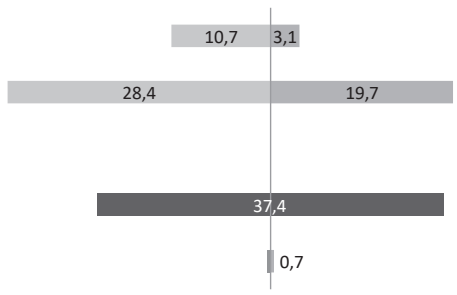

Dane wyrażone $w \% ; n=1003=100 \%$.

Źródło: badania własne.

Uznanie dla lokalnych władz samorządowych, które sprawowane są od niemal dziesięciu lat pod kierownictwem tego samego prezydenta', wyrażane jest mniej więcej równie często przez mieszkańców urodzonych w Szczecinie, jak i tu osiedlonych, podobnie jest w wymiarze szczecińskich korzeni rodzinnych lub ich braku. Na uwage zasługuje jednak pewność wyrażanych opinii, zarówno tych pozytywnych, jak i negatywnych, jest ona wyraźnie wyższa wśród szczecinian z urodzenia oraz tych, którzy mają szczecińskie korzenie w rodzinach. Oni też charakteryzują się wyższym poziomem krytycyzmu wobec władzy. Różnica wyrażana kilkunastoma punktami procentowymi w porównaniu ze szczecinianami tu 
niezakorzenionymi stanowi jedną z istotnych cech charakteryzujących zbiorowość mieszkańców. Można wręcz powiedzieć, że o ile poziom pozytywnej percepcji samorządu lokalnego wśród szczecinian zakorzenionych jest niemal taki sam jak wśród niezakorzenionych, o tyle ci drudzy, którzy dopiero się osiedlili lub nawet przyszli tu na świat, ale stanowią pierwsze pokolenie szczecinian w rodzinach, w niewielkim stopniu są skłonni do krytyki. Nie będąc całkowicie przekonani do pozytywnych ocen lokalnego samorządu terytorialnego, unikają raczej odpowiedzi, niż odrzucają stwierdzenie o dobrych władzach miasta, w którym teraz żyją. Jest to szczególnie zrozumiałe, jeśli wziąć pod uwagę kontekst awansu społecznego, jakim jest przeprowadzka do dużego miasta - centrum regionu

Wykres 2

Rozkład opinii na temat stwierdzenia Szczecin ma dobre władze ze względu na genezę szczecińskiej tożsamości mieszkańców w wieku 25-44 lata i ze względu na szczecińskie korzenie rodzinne

Stwierdzenie 1: Szczecin ma dobre władze
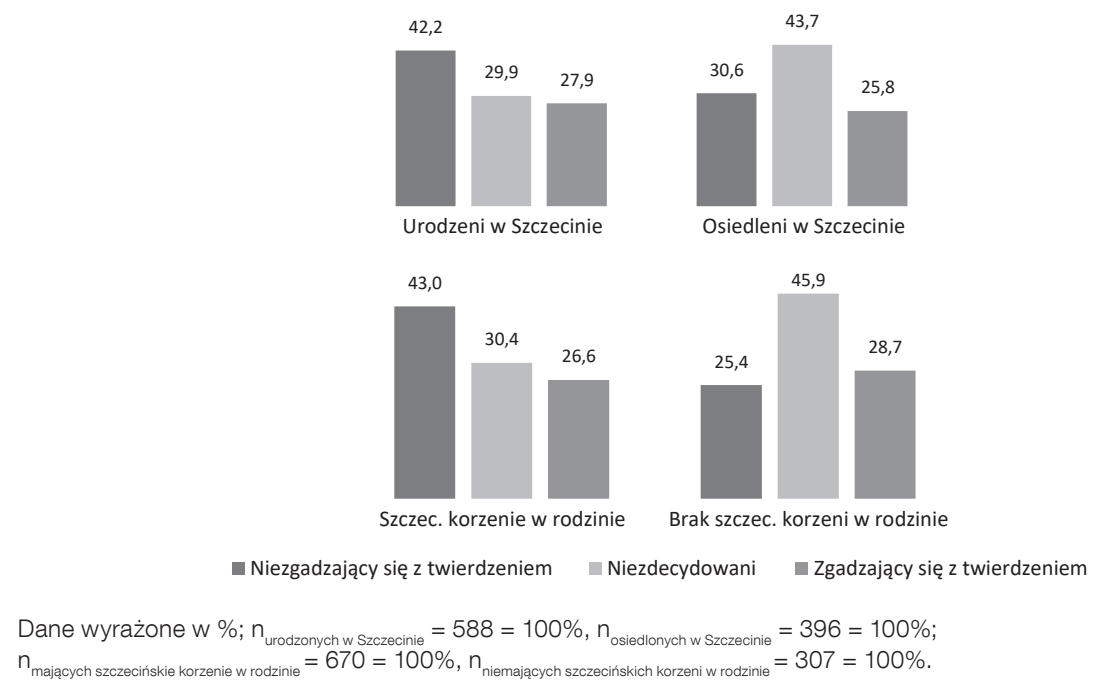

Test Chi-kwadrat dla zależności między rozkładem opinii na temat stwierdzenia Szczecin ma dobre władze a genezą szczecińskiej tożsamości

$\begin{array}{lccc}\text { Statystyki } & \text { Wartości } & \text { df } & \text { Poziomy istotności } \\ \text { Chi-kwadrat Pearsona } & 21,54 & 2 & 0,00 \\ \text { Wskaźnik wiarygodności } & 21,52 & 2 & 0,00 \\ \text { Test trendu } & 3,35 & 1 & 0,07 \\ \text { Liczebność ważnych przypadków } & 984 & & \\ \text { Współczynnik siły związku C } \text { kor }_{\text {-Pearsona }} & 0,19 & & \end{array}$

Test Chi-kwadrat dla zależności między rozkładem opinii na temat stwierdzenia Szczecin ma dobre władze a zmienną szczecińskie korzenie w rodzinie

$\begin{array}{lccc}\text { Statystyki } & \text { Wartości } & \text { df } & \text { Poziomy istotności } \\ \text { Chi-kwadrat Pearsona } & 31,99 & 2 & 0,00 \\ \text { Wskaźnik wiarygodności } & 32,64 & 2 & 0,00 \\ \text { Test trendu } & 12,79 & 1 & 0,00 \\ \text { Liczebność ważnych przypadków } & 977 & & \\ \text { Współczynnik siły związku C } \text { kor }_{\text {-Pearsona }} & 0,23 & & \end{array}$

Źródło: badania własne. 
z mniejszych miejscowości województwa. Więcej jeszcze, zjawisko to nosi znamiona racjonalizacji podjętych decyzji i dokonanego wyboru, by przyszłość związać z miastem, w którym zamierza się żyć i realizować aspiracje.

Podobnie jak w przypadku stwierdzenia Szczecin ma dobre władze zmienna geneza szczecińskiej tożsamości oraz zmienna szczecińskie korzenie rodzinne różnicują opinie formułowane przez mieszkańców w odniesieniu do stwierdzenia: Władza w Szczecinie słabo radzi sobie z tworzeniem warunków sprzyjających rozwojowi miasta, choć poziom aprobaty dla władz lokalnych jest tu niższy. Ogólnie rzecz ujmując, nieco częściej niż co piąty

\section{Wykres 3}

Rozkład opinii na temat stwierdzenia Władza w Szczecinie słabo radzi sobie z tworzeniem warunków sprzyjających rozwojowi miasta ze względu na genezę szczecińskiej tożsamości mieszkańców w wieku 25-44 lata i ze względu na szczecińskie korzenie rodzinne

Stwierdzenie 2: Władza w Szczecinie słabo radzi sobie z tworzeniem warunków sprzyjających rozwojowi miasta
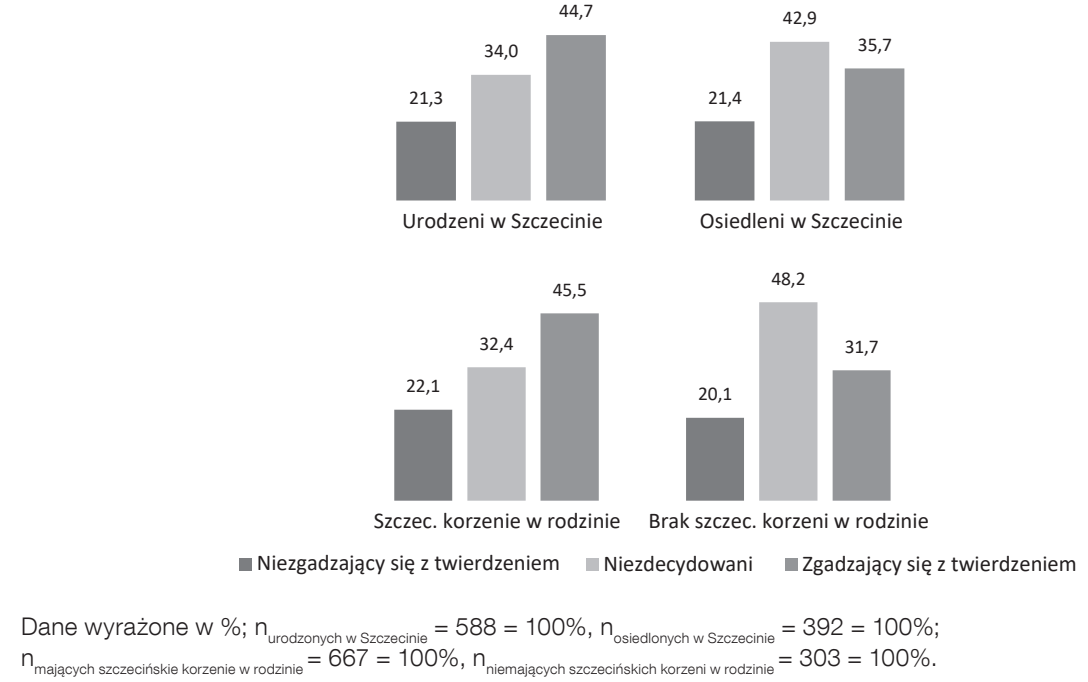

Test Chi-kwadrat dla zależności między rozkładem opinii na temat stwierdzenia Władza w Szczecinie słabo radzi sobie z tworzeniem warunków sprzyjających rozwojowi miast a genezą szczecińskiej tożsamości

\section{Statystyki}

Chi-kwadrat Pearsona

Wskaźnik wiarygodności

Test trendu

Liczebność ważnych przypadków

Współczynnik siły związku $C_{\text {kor }}$-Pearsona

Wartości
9,55
9,56
3,39
980
0,13

df

2

2

1

Poziomy istotności

0,01

0,01

0,07

Test Chi-kwadrat dla zależności między rozkładem opinii na temat stwierdzenia Władza w Szczecinie słabo radzi sobie z tworzeniem warunków sprzyjających rozwojowi miast a zmienną szczecińskie korzenie w rodzinie

\section{Statystyki}

Chi-kwadrat Pearsona

Wskaźnik wiarygodności

Test trendu

Liczebność ważnych przypadków

Współczynnik siły związku $\mathrm{C}_{\text {kor }}$-Pearsona

Źródło: badania własne.

$\begin{array}{ccc}\text { Wartości } & \text { df } & \text { Poziomy istotności } \\ 24,02 & 2 & 0,00 \\ 23,90 & 2 & 0,00 \\ 5,00 & 1 & 0,03 \\ 973 & & \\ 0,20 & & \end{array}$


mieszkaniec pozytywnie ocenia działania samorządu lokalnego Szczecina w zakresie tego, jak radzi sobie on z tworzeniem warunków sprzyjających rozwojowi, przy czym pomimo że wyższy poziom krytycyzmu charakteryzuje szczecinian z urodzenia oraz tych, którzy mogą się pochwalić szczecińskimi korzeniami w rodzinie, wyraźna jest przewaga (o kilkanaście punktów procentowych) opinii negatywnych wśród mieszkańców napływowych

Wykres 4

Rozkład opinii na temat stwierdzenia To, co jest dobre w Szczecinie, częściej jest marnotrawione niż wykorzystywane dla jego świetności ze względu na genezę szczecińskiej tożsamości mieszkańców w wieku 25-44 lata i ze względu na szczecińskie korzenie rodzinne

Stwierdzenie 3: To, co jest dobre w Szczecinie, częściej jest marnotrawione niż wykorzystywane dla jego świetności

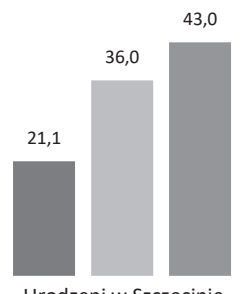

Urodzeni w Szczecinie

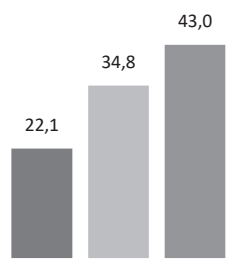

Szczec. korzenie w rodzinie

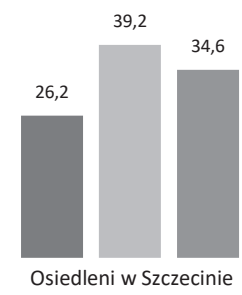

42,2

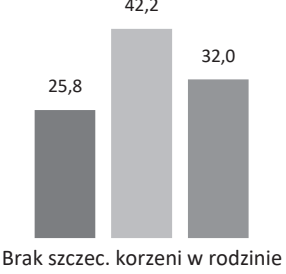

niezgadzający się z twierdzeniem $\quad$ Niezdecydowani $\quad$ Zgadzający się z twierdzeniem

Dane wyrażone w \%; $n_{\text {urodzonych w Szczecinie }}=589=100 \%, n_{\text {osiedlonych } w \text { Szczecinie }}=393=100 \% ;$
$n_{\text {maincy }}=306=100 \%$.

Test Chi-kwadrat dla zależności między rozkładem opinii na temat stwierdzenia To, co jest dobre w Szczecinie częściej jest marnotrawione niż wykorzystywane dla jego świetności a genezą szczecińskiej tożsamości

\section{Statystyki}

Chi-kwadrat Pearsona

Wskaźnik wiarygodności

Test trendu

Liczebność ważnych przypadków

Współczynnik siły związku $\mathrm{C}_{\text {kor }}$-Pearsona

Wartości
7,50
7,53
7,16
982
0,11

df

2

2

1

Test Chi-kwadrat dla zależności między rozkładem opinii na temat stwierdzenia To, co jest dobre w Szczecinie częściej jest marnotrawione niż wykorzystywane dla jego świetności a zmienną szczecińskie korzenie w rodzinie

\section{Statystyki}

Chi-kwadrat Pearsona

Wskaźnik wiarygodności

Test trendu

Liczebność ważnych przypadków

Współczynnik siły związku $C_{\text {kor }}$-Pearsona

Źródło: badania własne.

\section{Wartości}

10,71

10,88

7,55

975

0,14
Poziomy istotności

0,00

0,00

0,01 
oraz tych, którzy nie mają szczecińskich korzeni w rodzinie. Związek między stosunkiem do jakości warunków rozwojowych tworzonych przez lokalne władze a zmiennymi zakorzenienia pokazuje również czytelną przewagę osób niezdecydowanych wśród tych, które nie są ze Szczecinem związane poprzez urodzenie lub korzenie rodzinne. Niemniej we wszystkich kategoriach mieszkańców tylko mniej więcej co piąty uważa, że działania władz lokalnych w zakresie tworzenia warunków sprzyjających rozwojowi miasta są zadowalające. Można w zasadzie mówić o liczącej niemal osiemdziesiąt procent kategorii szczecinian mieszczących się w aktywnych kategoriach wieku produkcyjnego, którzy nie lokują swoich opinii o sposobie sprawowania władzy przez lokalny samorząd w obszarze satysfakcji i zadowolenia.

Szczególnym aspektem oceny jakości działań prorozwojowych realizowanych przez władze lokalne jest sposób wykorzystywania szeroko rozumianych zasobów miasta, czyli wszystkiego tego, co postrzegane jest jako wartościowe, wyjątkowe, lepsze niż w innych miastach czy po prostu na tyle atrakcyjne, że może stanowić bazę lub chociaż wzmocnienie dla tego, co dziać się w mieście powinno i czego w istocie mieszkańcy oczekują. W takiej perspektywie percepcji wykorzystania dostępnych kapitałów szczecińskie władze postrzegane są jako podmiot niezbyt dobrze gospodarujący. Jedynie nieco częściej niż co piąty mieszkaniec miasta nie zgadza się ze stwierdzeniem: To, co jest dobre w Szczecinie, częściej jest marnotrawione niż wykorzystywane dla jego świetności, z czego można wnosić o istniejących deficytach zadowolenia istniejących w tym obszarze świadomości społecznej mieszkańców, który odnosi się do mądrego gospodarowania jego zasobami oraz kierowania jego rozwojem w sposób zgodny z wyobrażeniami o tym, jak współczesne aglomeracje powinny się rozwijać i jakie warunki życia powinni mieć ich mieszkańcy. Podwyższony poziom krytycyzmu charakteryzujący mieszkańców zakorzenionych w Szczecinie pokazuje niezadowolenie z tego, jak miasto się rozwija.

Reasumując, można powiedzieć, że wśród szczecinian dominuje przekonanie o tym, iż władze miasta nie działają tak, jak należałoby tego oczekiwać. Nie radzą sobie z tworzeniem warunków dogodnych dla rozwoju, a dostępne zasoby są niewykorzystywane czy wręcz marnotrawione. To niezadowolenie ze sposobu zarządzania miastem podlega różnicowaniu przez zmienne zakorzenienia. Czytelna jest bowiem przewaga opinii negatywnych odnoszących się do ogólnego stwierdzenia Szczecin ma dobre władze, wypowiadanych przez mieszkańców genetycznie z miastem związanych, niż ma to miejsce w przypadku szczecinian w mieście niezakorzenionych. Pokazuje to swoistą przestrzeń nadziei oraz kredyt zaufania udzielany zespołowi zarządzającemu miastem przez część mieszkańców, którzy jako osiedleńcy i/lub osoby bez szczecińskich korzeni w rodzinie ciągle nie czują się tu na tyle u siebie, by w sposób otwarty krytykować lokalny samorząd, odmawiając mu statusu „dobrej władzy”. Inaczej ma się to w odniesieniu do konkretnych, obserwowanych przez mieszkańców - jeśli nie na co dzień, to w stosunkowo niedługim okresie - działań realizowanych przez włodarzy miasta, które powinny skutkować wzrostem dynamiki rozwoju społeczno-gospodarczego, jakości życia mieszkańców, a przez to również konkurencyjności co najmniej regionalnej. Niedomagania i deficyty w tym zakresie sygnalizowane są częściej również przez mieszkańców budujących dopiero swoje związki ze Szczecinem. 


\section{O potencjale rozwojowym i możliwościach rozwoju osobistego}

Miasto jako przestrzeń życia ogniskuje w sobie wiele elementów stanowiących ramy dla zachodzących tu procesów społeczno-gospodarczych, kulturowych oraz demograficznych. Jest przestrzenią lokalizacji różnego rodzaju praktyk społecznych zorientowanych na osiąganie określonych celów, realizowanych przez liczne podmioty gospodarcze i społeczne, jak również przez konkretnych mieszkańców. Przestrzeń ta stanowi zatem kompleks warunków tworzących środowisko podejmowanych działań, którego jakość nie pozostaje bez znaczenia dla ich efektywności. Więcej jeszcze, warunki te są szczególnie ważne w tych sferach działalności, w których istotne są nie tylko czynniki infrastrukturalne (np. system dróg, baza lokalowa, istnienie określonych instytucji) lub położenie geograficzne, lecz także tam, gdzie chodzi o pewien rodzaj pozytywnej atmosfery pojawiającej się wszędzie, gdzie skupiają się ludzie przedsiębiorczy, gdzie pojawiają się inicjatywy wynikające z nieagresywnej rywalizacji i współpracy, gdzie napływa kapitał, a to, co się w związku z tym wszystkim dzieje, jest postrzegane przez uczestników oraz aktorów zewnętrznych jako dynamiczny a przez to godny uznania - rozwój. Tego rodzaju energia pojawiająca się w mieście tworzy jego potencjał rozwojowy oraz daje mieszkańcom możliwości rozwoju osobistego, lecz jednocześnie tworzy jego atrakcyjność osiedleńczą oraz - co nie jest bez znaczenia - regionalną konkurencyjność. Jest ona również przedmiotem przekonań mieszkańców miasta oraz tych, którzy rozpatrują związanie z nim swoich planów życiowych. Ryszard Czyszkiewicz i Włodzimierz Durka (2011), portretując szczecińską przedsiębiorczość, piszą o tym w taki sposób:

Prognozy na temat najbliższej przyszłości, aczkolwiek odnoszą się do sfery subiektywnej, są w ogóle bardzo istotną sprawą w działalności gospodarczej, i nie tylko, bo wpływają także na sferę społeczną i obywatelską. Decydują one nie tylko o atmosferze społecznej, o stanie ducha i nastrojów obywateli, ale rzutować mogą na podejmowane decyzje, np. o zamknięciu zakładu lub chociażby ograniczeniu działalności albo niepodejmowaniu wysiłków inwestycyjnych. Należy tutaj uwzględnić odpowiedni horyzont czasowy - musi on być postrzegalny jako realny i dotyczący niezbyt odległej przyszłości. Dodatkowo nastroje, oczekiwania, obawy i nadzieje koncentrują się wokół podmiotów o różnym zakresie ogólności. (...) największą wiarę w polepszenie warunków działania przedsiębiorcy wykazują w odniesieniu do sytuacji we własnej firmie, nawet jeśli przyszłość całej ich branży nie jawi się różowo. Perspektywy rozwoju sytuacji w mieście ocenia się gorzej, a w niektórych momentach nawet bardzo źle (s. 306-307, 310).

Dla charakterystyki tego wymiaru posłużono się w prezentowanym badaniu czterema stwierdzeniami. Stwierdzenie pierwsze odnosi się do atmosfery otaczającej ludzi z inicjatywą: W Szczecinie panują dogodne warunki dla osiągnięcia sukcesu przez ludzi z inicjatywą. Stwierdzenie drugie pokazuje komparatywny wymiar przekonań szczecinian o warunkach rozwojowych w mieście: Jeśli ktoś ma wysokie ambicje zawodowe, to większe szanse na ich spełnienie dają inne niż Szczecin duże miasta Polski. Podobnie stwierdzenie trzecie, odwołujące się do oceny osobistych szans rozwojowych: Gdybym żyła/żył w innym dużym mieście Polski, to miałabym/miałbym większe możliwości realizacji celów. Stwierdzenie czwarte natomiast traktuje o sposobach myślenia na temat Szczecina, dla których tło stanowią wyobrażenia oraz wiedza o tym, jak rozwijają się inne miasta w Polsce: Inne duże miasta Polski rozwijają się szybciej niż Szczecin.

Zestawione na wykresie 5 rozkłady opinii dotyczących treści wymienionych stwierdzeń stanowią wieńczącą niejako część prowadzonych dotychczas rozważań związanych 
Ocena możliwości osobistego rozwoju w Szczecinie - zestawienie rozkładów opinii (\%)

W Szczecinie panują dogodne warunki dla osiągnięcia sukcesu przez ludzi z inicjatywą

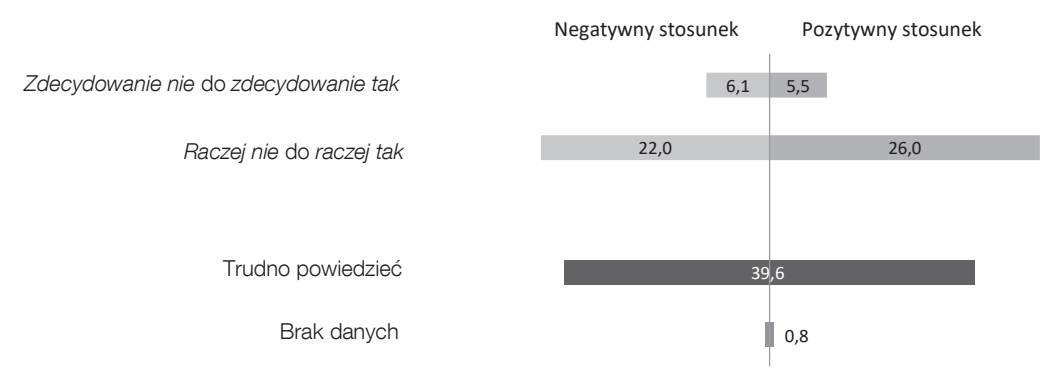

Jeśli ktoś ma wysokie ambicje zawodowe, to większe szanse na ich spełnienie dają inne niż Szczecin duże miasta Polski
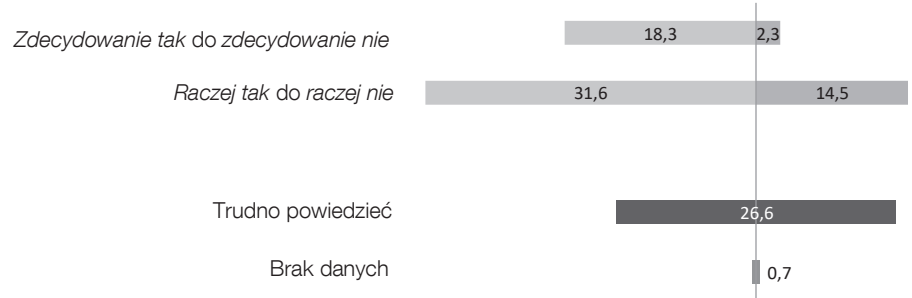

Gdybym żyła/żył w innym dużym mieście Polski, to miałabym/miałbym większe możliwości realizacji celów

Zdecydowanie tak do zdecydowanie nie
Raczej tak do raczej nie
Trudno powiedzieć
Brak danych

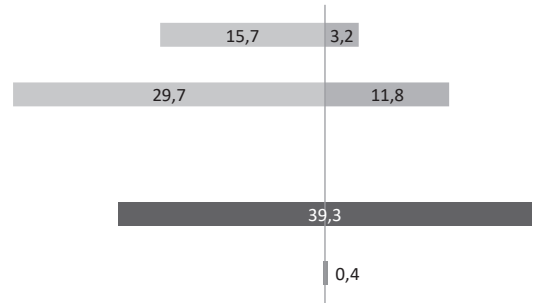

Inne duże miasta Polski rozwijają się szybciej niż Szczecin
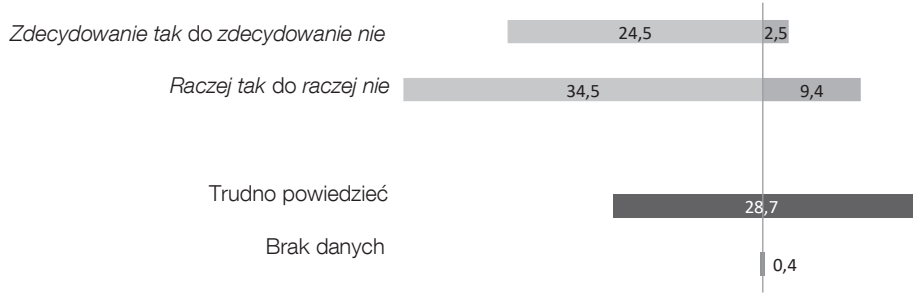

$\mathrm{n}=1003=100 \%$.

Źródło: badania własne. 
z ogólnym stosunkiem do Szczecina, stosunkiem do jego mieszkańców oraz aktualnych władz. Analiza przekonań odnoszących się do tych stwierdzeń skoncentrowanych na potencjale rozwojowym oraz możliwościach rozwoju osobistego oferowanych przez miasto pozwala dostrzec dynamiczny aspekt tego, jak funkcjonuje ono w świadomości stosunkowo młodych mieszkańców, należących do najbardziej atrakcyjnych rynkowo kategorii wieku produkcyjnego. Chodzi przy tym o ten wymiar dynamiki świadomościowego obrazu miasta, który zawiera w sobie z jednej strony wyniki osobistych doświadczeń jego mieszkańców, a z drugiej refleksy nadziei oraz wyobrażeń o tym, jak mogłoby być, a w zasadzie jak być powinno. Dlatego opinie wyrażane przez szczecinian w tej części prezentowanych badań pokazują w istocie społeczną percepcję istniejących w mieście potencjałów rozwojowych oraz ocenę poziomu ich wykorzystania. Ten kontekst istniejących w mieście zasobów oraz oddziałujących na nie impulsów rozwojowych - generowanych w jego wnętrzu (przez władze, podmioty gospodarcze czy mieszkańców) lub pochodzących z otoczenia jest przedmiotem świadomościowej obróbki, jak również powstających w jej wyniku przekonań o tym, że stolica Pomorza Zachodniego jest środowiskiem sprzyjającym odnoszeniu sukcesów, wzmacniającym podejmowane wysiłki i inspirującym do kolejnych działań lub przeciwnie, że jest przestrzenią demotywującą i w zasadzie można tu znaleźć raczej przeszkody i bariery niż progi, z których można się wybić na wyżyny własnych możliwości, przy czym oczywiście między tymi dwoma skrajnymi opiniami rozciąga się obszar potencjalnych mniej wyrazistych przekonań.

Zestawienie opinii szczecinian uczestniczących w badaniu na temat rozwojowego oblicza miasta pozwala na dostrzeżenie kilku istotnych, z perspektywy tożsamości lokalnej, cech sposobu, w jaki myśli się o Szczecinie jako miejscu lokowania realizacji życiowych i zawodowych planów na przyszłość. Po pierwsze, trzeba zauważyć przewagę ogólnie negatywnego nastawienia do warunków i możliwości rozwojowych, jakimi dysponuje Szczecin. Nawet jeżeli pojawiają się opinie świadczące o przekonaniu, że ludzie z inicjatywą mogą odnosić w Szczecinie sukcesy, to towarzyszy temu znacząca liczebność postaw niezdecydowanych (39,6\%). Po drugie, daje się zauważyć różnica w myśleniu o tym, jak miasto i jego zasoby rozwojowe sprzyjają osiąganiu sukcesu w zależności od tego, czy prosi się szczecinian o sformułowanie opinii na ten temat w odniesieniu do samego tylko Szczecina, czy istniejące w nim warunki oceniane są na tle innych dużych ośrodków miejskich w kraju. Zatem o ile niemal co trzeci szczecinianin (31,5\%) twierdzi, że w Szczecinie panują dogodne warunki do osiągnięcia sukcesu przez ludzi z inicjatywą, o tyle w przypadku trzech pozostałych stwierdzeń, które rozpatrują stolicę Pomorza Zachodniego na tle innych miast, liczba opinii pozytywnych jest zdecydowanie niższa. Z twierdzeniem, że inne miasta Polski rozwijają się szybciej niż Szczecin, nie zgadza się jedynie mniej więcej co dziesiąty uczestnik badania (11,9\%). Szczecin jest zatem rozpoznawany raczej jako miasto o słabej dynamice rozwoju, w którym jeżeli nawet istnieją dogodne warunki dla osiągania sukcesu, to wymagana jest własna inicjatywa, choć i tak w innych miastach - o czym przekonana jest duża część uczestników badania - warunki są bardziej sprzyjające.

Więcej światła na omawiane zagadnienia rzuca zestawienie rozkładów opinii na temat stwierdzeń odwołujących się do ogólnie rozumianego potencjału rozwojowego Szczecina ze zmiennymi dotyczącymi zakorzenienia, czyli genezą szczecińskiej tożsamości oraz szczecińskimi korzeniami w rodzinie. Wpływ obu zmiennych jest wydatny, co daje się dostrzec już w przypadku pierwszego z analizowanych stwierdzeń, gdy dostrzegając echo awansu społecznego, jakim jest przeprowadzka do dużego miasta, wyraźnie widać, 
Rozkład opinii na temat stwierdzenia W Szczecinie panują dogodne warunki dla osiągnięcia sukcesu przez ludzi z inicjatywą ze względu na genezę szczecińskiej tożsamości mieszkańców w wieku 25-44 lata i ze względu na szczecińskie korzenie rodzinne

Stwierdzenie 1: W Szczecinie panują dogodne warunki dla osiągnięcia sukcesu przez ludzi z inicjatywą

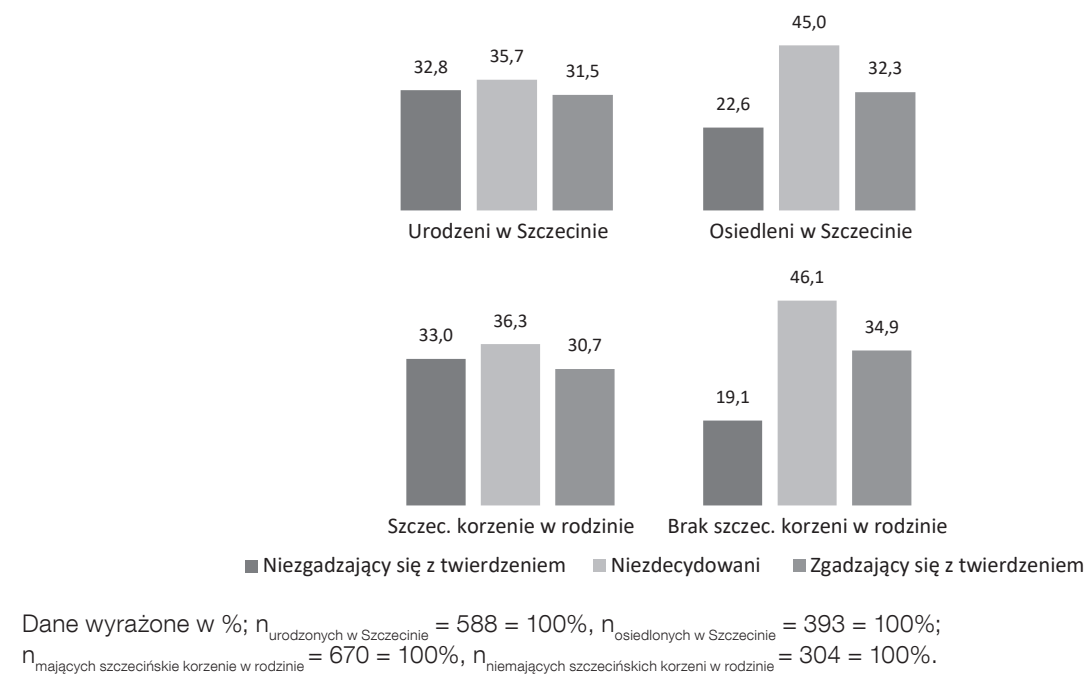

Test Chi-kwadrat dla zależności między rozkładem opinii na temat stwierdzenia W Szczecinie panują dogodne warunki dla osiągnięcia sukcesu przez ludzi z inicjatywą a genezą szczecińskiej tożsamości

\section{Statystyki}

Chi-kwadrat Pearsona

Wskaźnik wiarygodności

Test trendu

Liczebność ważnych przypadków

Współczynnik siły związku $\mathrm{C}_{\text {kor }}$-Pearsona

$\begin{array}{cc}\text { Wartości } & \\ 13,73 & 2 \\ 13,92 & 2 \\ 4,74 & \\ 981 & \\ 0,15 & \end{array}$

\section{df}

2

1

Poziomy istotności

0,00

0,00

0,03

Test Chi-kwadrat dla zależności między rozkładem opinii na temat stwierdzenia W Szczecinie panują dogodne warunki dla osiągnięcia sukcesu przez ludzi z inicjatywą a zmienną szczecińskie korzenie w rodzinie

\section{Statystyki}

Chi-kwadrat Pearsona

Wskaźnik wiarygodności

Test trendu

Liczebność ważnych przypadków

Współczynnik siły związku $\mathrm{C}_{\text {kor }}$-Pearsona

Źródło: badania własne.

$\begin{array}{ccc}\text { Wartości } & \text { df } & \text { Poziomy istotności } \\ 20,32 & 2 & 0,00 \\ 21,26 & 2 & 0,00 \\ 11,21 & 1 & 0,00 \\ 975 & & \\ 0,19 & & \end{array}$

że przekonanie o tym, iż w Szczecinie panują dogodne warunki dla osiągnięcia sukcesu przez ludzi z inicjatywą, w podobnym stopniu podzielają zarówno urodzeni w Szczecinie, jak i tu osiedleni, mający w rodzinie szczecińskie korzenie, jak i ci, którzy ich nie mają. Różnica staje się wyraźna, jeśli wziąć pod uwagę brak zgody z powyższym stwierdzeniem; tutaj wyraźnie częściej krytycznie o Szczecinie wypowiadają się w nim urodzeni oraz ci, którzy mają szczecińskie korzenie w rodzinie. Mieszkańcy niezakorzenieni skłonni są raczej unikać negatywnych opinii, uciekając w sferę niedopowiedzenia i niepewności. Jeżeli wziąć pod uwage jeszcze i to, że opinie w odniesieniu do tego stwierdzenia różnicuje poziom 
wykształcenia, można stwierdzić, że fakt napływu do Szczecina, brak rodzinnych związków z tym miastem oraz wyższe wykształcenie łączą się z podwyższonym poziomem wiary w to, że mając dobrą inicjatywę, można tu osiągnąć sukces. I odwrotnie, optymizm ten wyraźnie rzadziej podzielany jest przez gorzej wykształconych szczecinian z urodzenia, tych z rodzinnymi korzeniami w stolicy Pomorza Zachodniego.

\section{Wykres 7}

Rozkład opinii na temat stwierdzenia Jeśli ktoś ma wysokie ambicje zawodowe, to większe szanse na ich spełnienie dają inne niż Szczecin duże miasta Polski ze względu na genezę szczecińskiej tożsamości mieszkańców w wieku 25-44 lata i ze względu na szczecińskie korzenie rodzinne

Stwierdzenie 2: Jeśli ktoś ma wysokie ambicje zawodowe, to większe szanse na ich spełnienie dają inne niż Szczecin duże miasta Polski

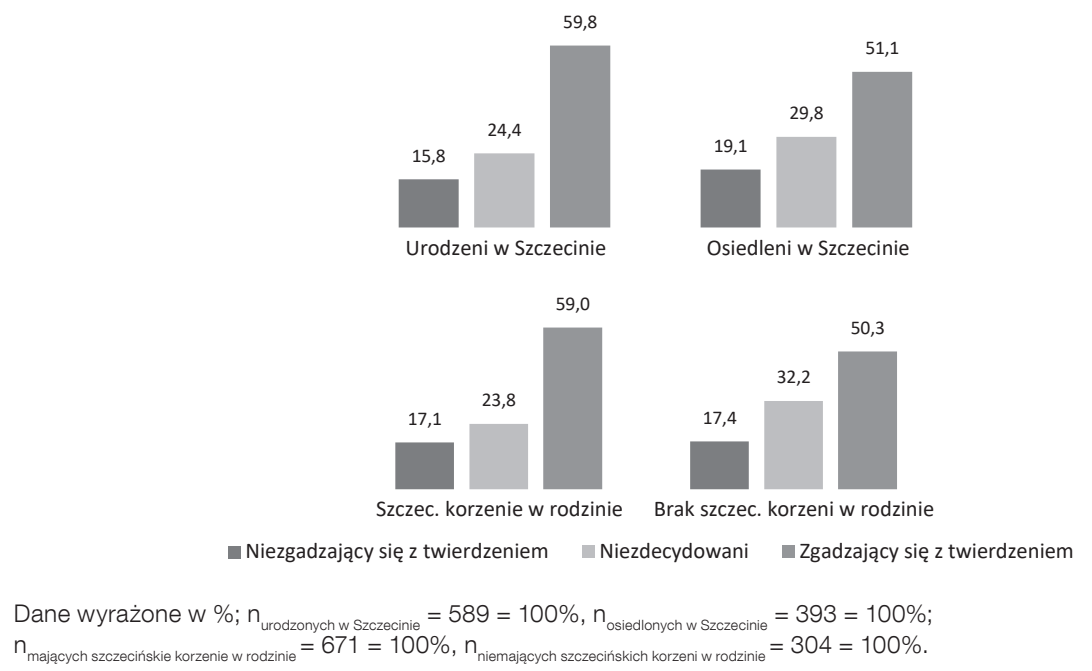

Test Chi-kwadrat dla zależności między rozkładem opinii na temat stwierdzenia Jeśli ktoś ma wysokie ambicje zawodowe, to większe szanse na ich spełnienie dają inne niż Szczecin duże miasta Polski a genezą szczecińskiej tożsamości

\section{Statystyki}

Chi-kwadrat Pearsona

Wskaźnik wiarygodności

Test trendu

Liczebność ważnych przypadków

Współczynnik siły związku $\mathrm{C}_{\text {kor }}$-Pearsona

Wartości
7,12
7,11
5,76
982
0,11

Test Chi-kwadrat dla zależności między rozkładem opinii na temat stwierdzenia Jeśli ktoś ma wysokie ambicje zawodowe, to większe szanse na ich spełnienie dają inne niż Szczecin duże miasta Polski a zmienną szczecińskie korzenie w rodzinie

\section{Statystyki}

Chi-kwadrat Pearsona

Wskaźnik wiarygodności

Test trendu

Liczebność ważnych przypadków

Współczynnik siły związku $\mathrm{C}_{\text {kor }}$-Pearsona

Źródło: badania własne.

$\begin{array}{ccc}\text { Wartości } & \text { df } & \text { Poziomy istotności } \\ 8,38 & 2 & 0,02 \\ 8,25 & 2 & 0,02 \\ 2,89 & 1 & 0,09 \\ 975 & & \\ 0,12 & & \end{array}$


Inaczej niż w przypadku stwierdzenia W Szczecinie panują warunki dogodne dla osiągania sukcesu przez ludzi z inicjatywą, z którym zgadza się niemal co trzeci szczecinianin, o połowę rzadsze (16,8\%) jest przekonanie, że Szczecin jest dobrym miejscem do realizacji wysokich ambicji zawodowych. Opinie w tym zakresie są zdecydowanie wyrazistsze, a mieszkańców miasta, którzy nie potrafią się w tej kwestii zdecydowanie opowiedzieć, jest o kilkanaście punktów procentowych mniej niż przy pierwszym stwierdzeniu. Pojawia się tu zatem świadomościowy obraz Szczecina jako miasta, w którym, owszem, istnieją warunki do osiągania sukcesu przez ludzi z inicjatywą, lecz jeśli ktoś ma rzeczywiście wysokie ambicje zawodowe, to raczej powinien realizować je gdzieś indziej. Ku takiemu rozumieniu specyfiki potencjału rozwojowego Szczecina bardziej skłaniają się szczecinianie tutaj „ukorzenieni” - w ich przekonaniu o awans społeczno-zawodowy łatwiej jest w innych dużych miastach Polski. Ten brak wiary w możliwości realizacji wysokich ambicji zawodowych w Szczecinie stanowi często element konstruujący warunki przyczynowe dla opuszczenia miasta. Dotyczy to szczególnie ludzi o wysokich kwalifikacjach zawodowych, ludzi o dużych ambicjach, pragnących intensywnego rozwoju zawodowego, lecz nieznajdujących na miejscu dostatecznych możliwości realizacji aspiracji (por. Terelak, Kołodziejczak, 2012a, s. 70). W takim kontekście przekonanie o braku możliwości zawodowego rozpostarcia skrzydeł w Szczecinie działa jak siła wypychająca z miasta, co jest szczególnie dotkliwe dla jakości szczecińskiego kapitału ludzkiego, gdyż dotyczy osób mocno zorientowanych na samorozwój - to przecież ich cechują wysokie ambicje zawodowe. O ile lepiej byłoby dla Szczecina, gdyby istniało tu przekonanie, że jest to dobre miejsce do realizacji wysokich ambicji zawodowych - wtedy ci najbardziej aktywni i wartościowi ze względu na tworzenie kapitału rozwojowego i wizerunkowego (a także tożsamościowego) miasta rzadziej myśleliby o jego opuszczeniu.

Innym z ważnych elementów tożsamości lokalnej jest przekonanie o tym, że miasto, w którym się żyje, jest przyjazne i sprzyja rozwojowi osobistemu oraz realizacji szeroko rozumianych celów życiowych. Ten aspekt stosunku do miejsca zamieszkania wydaje się kluczowy dla konstytuowania się więzi z miastem oraz jego instytucjami (szczególnie instytucjami władzy), a także zbiorowością mieszkańców. Przekonanie, że miasto jest odrębnym od innych podmiotem, a na dodatek podmiotem wyposażonym w pakiet cech i właściwości, które nawet jeśli same w sobie nie są unikatowe, to ich kombinacja świadczy o pewnej wyróżniającej specyfice, jest już oczywiście podstawą istnienia poczucia odrębności „my oni”, jednak nie bez znaczenia jest również sposób rozumienia (i oceny) tej odrębności. Jak się okazuje, wśród szczecinian mieszczących się w aktywnych kategoriach wieku produkcyjnego dominuje przekonanie, że jeśli Szczecin różni się od innych dużych miast, to głównie dlatego, że nie w nim, ale w tych innych miastach panują lepsze warunki do realizacji celów życiowych. Jest to zatem swoiste poczucie zamieszkiwania w gorszym miejscu, z czym oczywiście można się utożsamiać, lecz zwykle jest to tożsamość obarczona kompleksem niższości, a nawet niechciana - jeśli wziąć pod uwagę uzyskany w badaniach zrealizowanych w tym samym czasie na próbie studentów ostatnich lat szczecińskich uczelni wysoki odsetek osób deklarujących plany opuszczenia Szczecina². Dodatkowo można w tym miejscu przytoczyć obserwacje poczynione w trakcie badań nad zbiorowością

\footnotetext{
${ }^{2}$ W 2013 r. 39,4\% studentów szczecińskich uczelni pochodzących ze Szczecina deklarowało plany opuszczenia miasta po zakończeniu studiów, a w 2015 r. odsetek ten wynosił 43,0. Ten aspekt został poruszony w artykule napisanym wspólnie z Albertem Terelakiem (Szczecin jako przestrzeń życia i rozwoju w świadomości jego aktywnych zawodowo mieszkańców w kontekście rekompozycji rynków pracy Pomorza Zachodniego), zamieszczonym w niniejszym numerze „Opuscula Sociologica", i zilustrowany na wykresie 4 (s. 58).
} 
mieszkańców szczecińskiej dzielnicy Golęcino-Gocław, która cieszy się złą sławą dzielnicy niebezpiecznej dla osób tam niezamieszkałych. Lokalna społeczność właśnie ten wymiar własnego wizerunku traktowała jako najbardziej odróżniający od pozostałych części miasta, a mieszkańcy o ciemnych stronach dzielnicy wypowiadali się z niejaką dumą (por. Kowalewski, Kowalewski, Kołodziejczak, 2005; Kowalewski, Kołodziejczak, 2007).

Wykres 8

Rozkład opinii na temat stwierdzenia Gdybym żyła/żył w innym dużym mieście Polski, to miałabym/miałbym większe możliwości realizacji celów ze względu na genezę szczecińskiej tożsamości mieszkańców w wieku 25-44 lata i ze względu na szczecińskie korzenie rodzinne

Stwierdzenie 3: Gdybym żyła/żył w innym dużym mieście Polski, to miałabym/miałbym większe możliwości realizacji celów
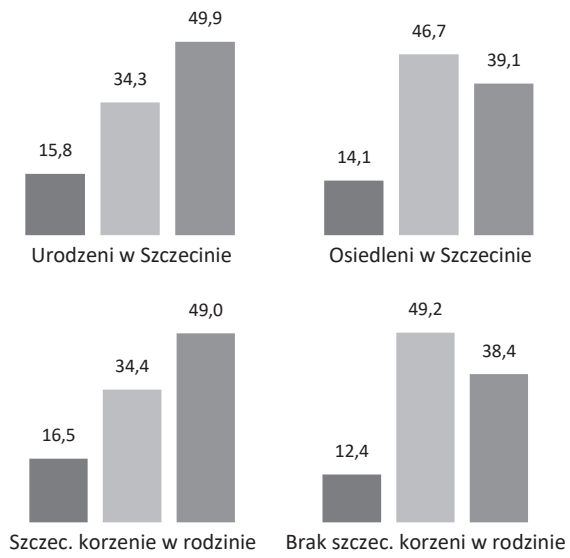

niezgadzający się z twierdzeniem Niezdecydowani \#gadzający się z twierdzeniem

Dane wyrażone w \%; $n_{\text {urodzonych w Szczecinie }}=589=100 \%, n_{\text {osiedlonych w Szczecinie }}=393=100 \% ;$
$n_{\text {mających szczecińskie korzenie w rodzinie }}=671=100 \%, n_{\text {niemających szczecińskich korzeni w rodzinie }}=307=100 \%$

Test Chi-kwadrat dla zależności między rozkładem opinii na temat stwierdzenia Gdybym żyła/żył w innym dużym mieście Polski. to miała/miałbym większe możliwości realizacji celów a genezą szczecińskiej tożsamości

\section{Statystyki}

Chi-kwadrat Pearsona

Wskaźnik wiarygodności

Test trendu

Liczebność ważnych przypadków

Współczynnik siły związku $C_{\text {kor }}$-Pearsona

Wartości
15,75
15,72
3,83
985
0,17

Poziomy istotności

0,00

0,00

0,05

Test Chi-kwadrat dla zależności między rozkładem opinii na temat stwierdzenia Gdybym żyła/żył w innym dużym mieście Polski. to miała/miałbym większe możliwości realizacji celów a zmienną szczecińskie korzenie w rodzinie

\section{Statystyki}

Chi-kwadrat Pearsona

Wskaźnik wiarygodności

Test trendu

Liczebność ważnych przypadków

Współczynnik siły związku $\mathrm{C}_{\text {kor }}$-Pearsona

Źródło: badania własne.

$\begin{array}{ccc}\text { Wartości } & \text { df } & \text { Poziomy istotności } \\ 19,32 & 2 & 0,00 \\ 19,11 & 2 & 0,00 \\ 1,68 & 1 & 0,19\end{array}$

978

0,18

Przekonanie zatem, że w innych miastach miałoby się lepsze warunki i możliwości realizacji celów życiowych, jest w Szczecinie na tyle rozpowszechnione, że nie podziela go 
jedynie 15,0\% mieszkańców należących do mobilnych kategorii wieku produkcyjnego, przy czym nieco częściej są to mieszkańcy zakorzenieni w mieście, czyli tacy, którym trudno jest znaleźć kontrargumenty dla tego, że są ludźmi stąd. Nadto - podobnie jak w przypadku innych stwierdzeń - ci ze szczecinian, którzy się tutaj nie urodzili oraz nie mają w rodzinach korzeni wiążących ich z miastem, są nastawieni nieco bardziej optymistycznie, choć jednocześnie częściej deklarują brak opinii.

Zauważone wcześniej przekonanie, że Szczecin jest gorszym miejscem od innych dużych miast Polski do realizacji celów życiowych, jeszcze wyraźniej daje się dostrzec w opiniach wyrażanych przez jego mieszkańców w odniesieniu do stwierdzenia Inne duże miasta Polski rozwijają się szybciej. Przewaga odpowiedzi stawiających Szczecin w niekorzystnym świetle jest tutaj najwyraźniejsza (łącznie 59,0\% zgadzających się ze stwierdzeniem wobec 11,9\% tych, którzy się z nim nie zgadzają). Taki świadomościowy obraz rozwoju Szczecina nie dziwi, gdy wziąć pod uwagę obserwowany od wielu lat proces znikania z mapy lokalnej przedsiębiorczości znaczących firm i zakładów pracy, szczególnie takich, które długoletnim istnieniem wpisały się w gospodarczy i społeczny krajobraz miasta, świadcząc o jego charakterze i wizerunku. Chodzi tu między innymi o Fabrykę Kabli „Załom”, Zakłady Włókien Sztucznych „Chemitex-Wiskord”, Hutę „Szczecin” czy nade wszystko Stocznię Szczecińską. I w tym miejscu można przywołać badania lokalnej przedsiębiorczości przeprowadzone przez Ryszarda Czyszkiewicza i Włodzimierza Durkę (2011), którzy pisząc o reperkusjach likwidacji Stoczni Szczecińskiej, zwracają uwagę, że:

Wydźwięk społeczny upadku stoczni miał kolosalne znaczenie dla każdego ze szczecinian, traktujących ten zakład jako symbol miasta. Wraz ze stocznią zniknęła także część miasta i było to bardzo boleśnie odczuwane przez każdego, nawet jeśli nie miał z nią żadnych osobistych powiązań. W następnych momentach badań nastroje się nieco stonowały, niemniej nastroje co do sytuacji w mieście są najgorsze ze wszystkich możliwych; już lepiej ocenia się perspektywy całego kraju (s. 310).

Cytowani badacze poddali analizie nastroje (pesymizm versus optymizm) szczecińskich przedsiębiorców odnoszone do przewidywanego rozwoju sytuacji w prowadzonych przez nich firmach, w całej branży (w której ramach działają prowadzone przez nich firmy), w Szczecinie oraz w całym kraju. Jak się okazało, najwyższy poziom pesymizmu prezentowali przedsiębiorcy w odniesieniu do przewidywanego rozwoju warunków w mieście. W 2009 roku 40,8\%, natomiast w 2010 - 27,7\% szczecińskich przedsiębiorców źle oceniało sytuację w mieście i z obawą spoglądało na rozwój sytuacji w swoim bezpośrednim miejskim otoczeniu (Czyszkiewicz, Durka, 2011, s. 310-312).

Zestawienie zebranych opinii ze zmiennymi zakorzenienia, które podobnie jak w przypadku opisywanych wcześniej stwierdzeń pokazują, że mieszkańcy niezwiązani genetycznie z miastem, niedawno osiedleni lub niemający rodzinnych powiązań ze Szczecinem wykazują stosunkowo wyraźną tendencję do szkicowania obrazu Szczecina w jaśniejszych barwach, niż jest to w przypadku szczecinian tu urodzonych i/lub mających rodzinne związki z miastem. Dysproporcje w dynamice rozwoju społeczno-gospodarczego Szczecina i innych dużych miast kraju są jednak na tyle wyraźne, a opinia o nich na tyle rozpowszechniona, że nawet pomimo wskazanej tendencji do rozjaśniania obrazu miasta przez mieszkańców napływowych, to i tak również oni (częściej unikając odpowiedzi - wybór „trudno powiedzieć") w niewielkim stopniu skłaniają się ku optymizmowi. 
Rozkład opinii na temat stwierdzenia Inne duże miasta Polski rozwijają się szybciej niż Szczecin ze względu na genezę szczecińskiej tożsamości mieszkańców w wieku 25-44 lata i ze względu na szczecińskie korzenie rodzinne

Stwierdzenie 4: Inne duże miasta Polski rozwijają się szybciej niż Szczecin

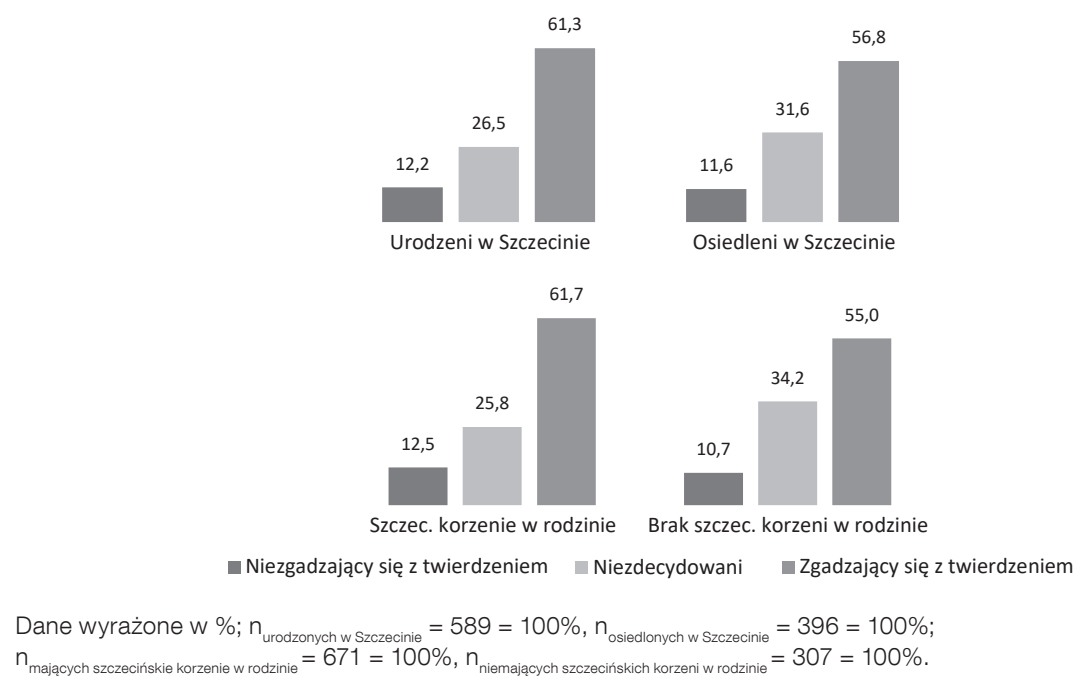

Test Chi-kwadrat dla zależności między rozkładem opinii na temat stwierdzenia Inne duże miasta Polski rozwijają się szybciej niż Szczecin a genezą szczecińskiej tożsamości

\section{Statystyki}

Chi-kwadrat Pearsona

Wskaźnik wiarygodności

Test trendu

Liczebność ważnych przypadków

Wartości
3,01
2,99
0,72
985

Poziomy istotności

0,22

0,22

0,40

Test Chi-kwadrat dla zależności między rozkładem opinii na temat stwierdzenia Inne duże miasta Polski rozwijają się szybciej niż Szczecin a zmienną szczecińskie korzenie w rodzinie

\section{Statystyki}

Chi-kwadrat Pearsona

Wskaźnik wiarygodności

Test trendu

Liczebność ważnych przypadków

Współczynnik siły związku $\mathrm{C}_{\text {kor }}$-Pearsona

Źródło: badania własne.

$\begin{array}{ccc}\text { Wartości } & \text { df } & \text { Poziomy istotności } \\ 7,37 & 2 & 0,03 \\ 7,23 & 2 & 0,03 \\ 1,03 & 1 & 0,31 \\ 978 & & \\ 0,11 & & \end{array}$

W obliczu nasilonego odpływu mieszkańców ze Szczecina oraz napływu ludności chcącej się tu osiedlić pojawia się pytanie o to, jak spowodować, by obecny w świadomości społecznej szczecinian obraz miasta zmieniał się tak, by nie tylko w dyskursie publicznym, lecz także w codziennych rozmowach na ulicy wyczuwalny stał się szczeciński genius loci wywołujący nadzieję i czyniący z mieszkańców prawdziwą wspólnotę. Tak, by jakość życia i perspektywy nie tylko nie były tu gorsze niż gdzie indziej, lecz także stanowiły atrakcyjny i czytelny obszar aktywizmu - inspirujący, stymulujący i wspomagający otoczenie. 


\section{LITERATURA}

Białek, J., Dzierzgwa, R., Mackiewicz, M., Perzanowska-Przychodzka, E., Przybylska, L., Siłuszek, A., Sudak, S., Więckowska, E. (2011). Raport Polska 2011. Gospodarka - Społeczeństwo - Regiony. Warszawa: Ministerstwo Rozwoju Regionalnego.

Czyszkiewicz, R., Durka, W. (2011). Topografia szczecińskiej przedsiębiorczości. Szkic socjologiczno-ekonomiczny. Szczecin: Centrum Rozwoju Społeczno-Gospodarczego.

Czyszkiewicz, R., Durka, W. (red.) (2016). Wspólnoty samorządowe województwa zachodniopomorskiego 2010-2015. Społeczeństwo - gospodarka - praca - dochody. Szczecin: Szczecińskie Towarzystwo Socjologiczne.

Kowalewski, J., Kowalewski, M., Kołodziejczak, S. (2005). Społeczność lokalna północnych dzielnic Szczecina wobec rewitalizacji (rejon ul. Światowida). Raport z badań socjologicznych. Szczecin: Fundacja na rzecz Uniwersytetu Szczecińskiego.

Kowalewski, M., Kołodziejczak, S. (2007). Dzielnica Golęcino-Gocław w Szczecinie jako przykład wielkomiejskiej strefy (samo)izolowanej. W: I. Machaj, L. Gołdyka (red.), Enklawy życia społecznego (s. 567-582). Szczecin: Wydawnictwo Naukowe Uniwersytetu Szczecińskiego.

Matczak, P., Jeran, A., Mączka, K., Nowak, M., Śliwa, P. (2015). Aktywizacja społeczna wspólnot terytorialnych w Polsce z perspektywy ćwierćwiecza samorządu terytorialnego. Ruch Prawniczy, Ekonomiczny i Socjologiczny, 3 (77), 77-89.

Terelak, A., Klepajczuk, B., Kołodziejczak, S. (2009). Poziom znajomości języków obcych wśród mieszkańców Szczecina i Koszalina oraz charakterystyka obcokrajowców studiujących w wyższych uczelniach obu miast. Raport z badania. Szczecin: Gmina Miasto Szczecin.

Terelak, A., Kołodziejczak, S. (2011). Poziom kompetencji językowych wśród mieszkańców Szczecina i Koszalina w zakresie wybranych języków obcych oraz charakterystyka obcokrajowców studiujących w wyższych uczelniach obu miast. Raport z badania. Szczecin: Gmina Miasto Szczecin.

Terelak, A., Kołodziejczak, S. (2012a). Praca za granicą w świadomości emigrantów zarobkowych z województwa zachodniopomorskiego. Szczecin: Wydawnictwo Zapol.

Terelak, A., Kołodziejczak, S. (2012b). Środowisko pracy w Polsce i za granicą w relacjach emigrantów zarobkowych z województwa zachodniopomorskiego. W: J. Leoński, L. Wątróbski (red.), Diaspora. Tom 5: Migracje Polaków - przeszłość i teraźniejszość. Zagadnienia teoretyczne oraz diaspora polska w Hiszpanii, Chorwacji, Francji, na Wegrzech, w Palestynie i Nowej Zelandii (s. 91-118). Szczecin: Ośrodek Studiów i Badań Polonijnych Uniwersytetu Szczecińskiego.

Terelak, A., Kołodziejczak, S. (2012c). Zagraniczne emigracje zarobkowe mieszkańców województwa zachodniopomorskiego a regionalny rynek pracy. Szczecin: Wydawnictwo Zapol.

Terelak, A., Kołodziejczak, S. (2013). Poziom kompetencji językowych - w zakresie języków obcych - wśród mieszkańców Szczecina mieszczących się w dynamicznych kategoriach wieku produkcyjnego oraz studentów szczecińskich uczelni wyższych stojących u progu wejścia na rynek pracy. Raport z badań. Szczecin: Gmina Miasto Szczecin.

Terelak, A., Kołodziejczak, S. (2016). Poziom kompetencji językowych - w zakresie języków obcych - wśród mieszkańców Szczecina mieszczących się w dynamicznych kategoriach wieku produkcyjnego oraz wśród stojących u progu wejścia na rynek pracy studentów szczecińskich uczelni. Raport z badań. Szczecin: Gmina Miasto Szczecin.

Terelak, A., Kołodziejczak, S. (w druku). Emigracje zarobkowe z Pomorza Zachodniego do Niemiec. W: Polen in Deutschland - Neue Formen, neue Welten und alte Traditionen. Chemnitz: Technische Universität Chemnitz. 


\section{KEYWORDS}

HUMAN CAPITAL,

PERCEPTION OF THE CITY;

SOCIAL IDENTITY, SOCIAL

ROOTING IN, LOCAL TIES
SUMMARY The article presents the results of the research concerned with the perception of the capital of West Pomerania by its inhabitants, conducted among the denizens within the mobile categories of working age (25-44). The findings presented in this paper address the issues of: 1) the attitude towards the Szczecin authorities, which allows for the assessment of the inhabitants' perception of the local authorities in the aspects chosen for the purposes of the research; 2) the potential for development and the conditions of personal development of the inhabitants, which constitute for the base of the city's attractiveness for settlement as well as its regional competitiveness. The significant context of the analysis is established through the comparison of the perceptions of the city along with the variables of inveteracy (having been born in Szczecin or having settled in it; having family roots in Szczecin or the lack of such). 